\title{
УДК:37:004
}

Дубініна Наталя Василівна аспірантка кафедри педагогіки Одеський національний педагогічний університет ім. К. Д. Ушинського, м. Одеса, Україна natali.dubinina@bk.ru

\section{ТЕХНОЛОГІЯ ВИКОРИСТАННЯ МУЛЬТИМЕДІА У НАВЧАЛЬНО-ВИХОВНОМУ ПРОЦЕСІ ТЕХНІЧНОГО ВНЗ ІНЖЕНЕРНО-БУДІВЕЛЬНОГО ПРОФІЛЮ}

\begin{abstract}
Анотація. Дана стаття присвячена опису технології використання мультимедіа у навчально-виховному процесі технічного вищого навчального закладу інженернобудівельного профілю в ході навчальної і майбутньої професійної діяльності. У ній розповідається про стадії підготовки майбутніх інженерів-будівельників до застосування засобів мультимедіа в ході навчальної і майбутньої професійної діяльності, а також про проведення констатувального i формувального експериментів, які доводять цілеспрямованість запропонованої методики, іiі ефективність і позитивні результати, що відображаються на сучасному навчальному процесі технічного вищого навчального закладу інженерно-будівельного профілю.
\end{abstract}

Ключові слова: готовність; модель; технологія; мультимедійна технологія; ВНЗ; інженербудівельник; майбутня професійна діяльність.

\section{1. ВСТУП}

Нині якість вищої освіти в Україні розглядається як один із важливих факторів стабільного розвитку країни. Підвищення якості вищої освіти - одне із найбільш глобальних питань, які поставлені нині перед наукою. Успішне виконання цього завдання залежить від застосування нових методів і технологій навчання, спрямованих на набуття знань, умінь та навичок, необхідних для здійснення навчальної і майбутньої професійної діяльності на сучасному етапі. 3 цією метою необхідно застосовувати нові мультимедійні технології, котрі допоможуть майбутнім спеціалістам засвоїти знання, набути вміння і навички, необхідні для реалізації майбутньої професійної діяльності, зроблять процес навчання більш цікавим, насиченим, ефективним та сучасним. Попри це, слід відзначити, що застосування нових мультимедійних технологій у ВН3 допомагають сформувати і розвинути професійно-особистісні якості, такі як: наукова позиція, уява, ініціатива, наукове судження, навички самостійної роботи i дослідницької діяльності.

Постановка проблеми. Відповідно із сучасною системою освіти постає необхідність забезпечити можливість практичного володіння студентами технічних ВН3 інженерно-будівельного профілю мультимедійними технологіями. Для цього потрібно розробити технологію, яка допоможе сучасним студентам отримати якісні знання, уміння та навички застосування засобів мультимедіа в ході навчальної i майбутньої професійної діяльності, завдяки яким вони будуть в змозі здійснювати майбутню професійну діяльність на високому рівні.

Мета статті - розробити технологію застосування мультимедіа у навчальновиховному процесі технічного ВНЗ інженерно-будівельного профілю.

Методи дослідження: бесіда, анкетування, тестування, спостереження, аналіз творчих робіт. 
Аналіз останніх досліджень та публікацій. Значну кількість робіт відомих педагогів і психологів присвячено проблемі готовності: М. І. Дяченко, Ф. І. Іващенко, Л. А. Кандибовича, Б. А. Ананьєва, В. А. Крутецького, А. А. Деркача, Ф. Генова, Е. П. Ільїна, Н. Д. Левітова, Л. С. Нерсесяна, В. Н. Пушкіна, Д. Н. Узнадзе, А. Ц. Пуні, I. М. Богданової, А. Ф. Линенко, А. І. Кочетова, І. Б. Котової, В. С. Мерліна, В. П. Андрющенко, Р. В. Ваврик, Л. І. Григорчука, П. І. Матвієнко, О. В. Волошиної, Л. С. Коржової, В. В. Арестенко, І. А. Ковальчук, Р. С. Гуріна, О. Б. Перець, К. М. Дурай-Новакової, Р. А. Гаспаряна, Е. Г. Козлова, Л. В. Конрашової, Н. В. Кузьміної, А. А. Нагорної, К. К. Платонова, В. Д. Шадрікова, Л. М. Конопляник, Л. П. Гапоненко, Є. С. Целих та інші.

У тлумачному словнику за редакцією В. Ушакова поняття «готовність» розглядається як згода зробити що-небудь, бажання сприяти чому-небудь. Тлумачний словник за редакцією С. Ожегова дає цьому феномену таке визначення: готовність це стан, за якого все зроблено, усе готове для чого-небудь. А. Ф. Линенко [6] трактує це поняття як цілісне стійке утворення, що мобілізує на включення в діяльність і вважає, що готовність набувається в результаті досвіду, що заснований на формуванні позитивного ставлення особистості до певного виду діяльності, усвідомлення мотивів і потреб у ній, об'єктивізації її предмета і засобів взаємодії з ним.

Такі вчені, як М. І. Дяченко [3], Л. А. Кандибович [4], Б. А. Ананьєв [1], В. А. Крутецький [5], А. А. Деркач [2] готовність до професійної діяльності розглядають як початкову активізацію людини, яка поєднує усвідомлення людиною своїх цілей, оцінювання наявних умов, визначення найбільш вірогідних способів дії; прогнозування мотиваційних, вольових, інтелектуальних зусиль, вірогідності досягнення результатів, мобілізацію сил, самонавіювання у досягненні цілей.

\section{2. РЕЗУЛЬТАТИ ДОСЛІДЖЕННЯ}

Під «готовністю майбутніх інженерів-будівельників до професійної діяльності в умовах застосування мультимедійних технологій» ми будемо розуміти інтегровану якість особистості майбутніх інженерів-будівельників, яке надає можливість ставити цілі, знаходити засоби їх досягнення, здійснювати самоконтроль за власними діями в умовах застосування засобів мультимедіа. Цей феномен містить уміння прогнозувати шляхи підвищення ефективності своєї професійної діяльності в умовах застосування мультимедійних технологій.

У структурі готовності майбутніх інженерів-будівельників в умовах застосування мультимедійних технологій нами було виділено чотири компоненти готовності: мотиваційний, змістовий, процесуально-діяльнісний і оцінний.

Мотиваційний компонент готовності до застосування мультимедійних технологій має на увазі інтерес студентів до використання мультимедійних технологій; усвідомлення доцільності застосування засобів мультимедіа у процесі навчання у ВНЗ; розуміння студентами значення і функцій застосування мультимедіа на заняттях і в майбутній професійній діяльності. Йому відповідає мотиваційно-особистісний критерій.

До змістовного компонента готовності до використання мультимедійних технологій належать теоретичні знання і вміння з предметів спеціального і соціальногуманітарного циклів; знання особливостей застосування мультимедійних технологій на заняттях як 3 профілюючих предметів, так і соціально-гуманітарних; сукупність знань, що дозволяє розробляти і використовувати засоби мультимедіа. Йому відповідає когнітивний критерій. 
Процесуально-діяльнісний компонент готовності передбачає наявність практичних умінь i навичок застосування мультимедійних програм у вивченні спеціальних i соціально-гуманітарних дисциплін; здатність i бажання студентів постійно вдосконалювати набуті вміння і навички для ефективного використання мультимедійних програм; створення сприятливої атмосфери на заняттях (уміння працювати із застосуванням засобів мультимедіа у групах і самостійно). Йому відповідає усвідомлено-практичний критерій.

Оцінний компонент готовності містить здатність до аналізу, мислення, наукового обгрунтування своїх ідей; здатність студентів до об'єктивного самоаналізу своєї роботи, а також до самовдосконалення своєї професійної діяльності в умовах застосування мультимедійних технологій. Йому відповідає рефлексивно-оціночний критерій.

3 метою розробки технології застосування мультимедіа у навчально-виховному процесі технічного ВНЗ інженерно-будівельного профілю необхідно виявити рівень готовності майбутніх інженерів-будівельників до використання мультимедіа, а також створити модель підготовки майбутніх інженерів-будівельників із застосуванням мультимедійних технологій, результатом якої стане їх готовність до застосування технологій даного виду впродовж навчальної і майбутньої професійної діяльності.

Протягом констатувального експерименту було застосовано такі методики: вивчення педагогічного досвіду із застосування мультимедійних технологій у професійній діяльності; анкетування майбутніх інженерів-будівельників 3 метою визначення рівня їх готовності застосовувати мультимедійні технології у майбутній професійній діяльності; бесіди, спостереження; аналіз їхніх професійно-творчих робіт (креслень, схем, будівельних проектів), тестування для виявлення навичок роботи студентів з мультимедійними технологіями, оцінювання рівня творчого потенціалу, здатності до самооцінки і самовдосконалення своїх професійних можливостей. Для визначення рівня мотивації студентів до застосування мультимедійних технологій ми взяли за основу методику І. С. Домбровської «Мотивація навчальної діяльності». Для визначення оцінки рівня творчого потенціалу ми використовували проективну методику Е. Торренса. Нами були отримані такі результати (див. табл. 1).

Таблиия 1

Рівні готовності майбутніх інженерів-будівельників до застосування мультимедійних технологій впродовж навчальної і майбутньої професійної діяльності [ за результатами констатувального експерименту (у \%)]

\begin{tabular}{|c|c|c|c|c|}
\hline Групи Рівні & Низький & Середній & Достатній & Високий \\
\hline ЕГ & 38 & 44 & 15 & 3 \\
\hline КГ & 34 & 40 & 20 & 6 \\
\hline
\end{tabular}

Отже, низький рівень готовності показали $38 \%$ студентів експериментальних груп і $34 \%$ студентів контрольних груп.

$\checkmark$ Середньому рівню відповідали $44 \%$ експериментальних $\quad$ і $40 \%$ контрольних груп.

$\checkmark$ Достатній рівень показали $15 \%$ експериментальних і $20 \%$ контрольних груп.

$\checkmark$ Високий рівень було виявлено у 6 \% експериментальних і $3 \%$ контрольних груп. 
Вищевикладене дозволяє зробити висновок, що у більшості досліджуваних погано сформований інтерес до застосування мультимедіа, a також бажання їх застосовувати впродовж навчальної і майбутньої професійної діяльності. Ми вважаємо, що причиною цьому є недостатня кількість мультимедійних аудиторі й, засобів мультимедіа, а також небажання викладачів проводити заняття за допомогою мультимедійних технологій.

Аналіз результатів констатувального експерименту підтверджує необхідність подальшого пошуку оптимальних шляхів і засобів удосконалення підготовки майбутніх інженерів-будівельників до застосування мультимедіа протягом навчальної i майбутньої професійної діяльності.

Формувальний експеримент базувався на виконанні наступних трьох педагогічних умов: набуття вмінь і навичок застосування мультимедійних технологій упродовж навчальної і майбутньої професійної діяльності; організація викладачами навчального процесу у ВНЗ на основі системного використання мультимедійних технологій; створення емоційної привабливості навчальної діяльності з використанням мультимедійних технологій.

Так, з метою реалізації першої педагогічної умови - набуття вмінь і навичок застосування мультимедійних технологій у ході навчальної і майбутньої професійної діяльності - майбутнім інженерам-будівельникам було запропоновано спецкурс «Мультимедійні технології на заняттях спеціального та соціально-гуманітарного циклів», який складався 3 теоретичного, методичного та практичного блоків. Ефективність засвоєння спецкурсу «Мультимедійні технології на заняттях спеціального та соціально-гуманітарного циклів» залежала від ступеня усвідомлення студентами застосування мультимедійних технологій для виконання навчальної i майбутньої професійної діяльності.

Програма розробленого нами спецкурсу розкриває перед майбутніми інженерамибудівельниками специфіку професійної діяльності із застосуванням мультимедійних технологій. Під час роботи над спецкурсом «Мультимедійні технології на заняттях спеціального та соціально-гуманітарного циклів» на лекційних заняттях студенти отримували теоретичні знання з проблеми застосування мультимедійних технологій у ході навчальної і майбутньої професійної діяльності, на практичних і семінарських заняттях - навчалися застосовувати мультимедійні технології на практиці, під час виконання самостійної та індивідуальної роботи - закріплювали набуті знання, уміння та навички, отримані у ході лекційних, практичних та семінарських занять.

3 метою реалізації другої педагогічної умови — організації навчального процесу на основі систематичного застосування мультимедіа — на заняттях використовувалися різні форми і методи роботи: студентам було продемонстровано мультимедійні презентації й анімаційні ролики на лекційних заняттях з предметів спеціального і соціально-гуманітарних циклів, обраних для проведення експерименту (геодезії, архітектурного проектування, інженерної графіки, англійської мови). На практичних заняттях було показано застосування комп'ютерних мультимедійних програм інженерного призначення.

Реалізація цієї педагогічної умови передбачає вибір викладачами методів, засобів навчання і напрямків роботи, де доцільно застосовувати мультимедійні технології, визначення ролі й місця мультимедіа на певних етапах заняття, поєднання традиційних методів навчання із застосуванням мультимедійних технологій, використовувати індивідуальний підхід до студентів у процесі роботи з мультимедіа.

Ця педагогічна умова була реалізована з метою застосування теоретичних знань специфіки мультимедійних технологій i набуття професійних умінь і практичних навичок застосування мультимедійних програм інженерно-будівельного призначення 
під час виготовлення будівельних креслень, проектів, виконання геодезичних робіт на місцевості у майбутній професійній діяльності.

Реалізація третьої педагогічної умови - створення емоційної привабливості навчальної діяльності $з$ використанням мультимедійних технологій — передбачала проведення занять, які будуть привабливими і комфортними для студентів, будуть розвивати інтерес студентів до навчального процесу, мотивувати студентів до застосування засобів мультимедіа і сприяти формуванню позитивних емоцій на заняттях.

Для створення емоційної привабливості навчальної діяльності з використанням мультимедійних технологій майбутнім інженерам-будівельникам на лекційних заняттях були показані відеоматеріали за змістом тем, які вивчалися на заняттях спеціального і соціально-гуманітарного циклів, таких як геодезія, інженерна графіка, архітектурне проектування та англійська мова 3 використанням мультимедіа, активних й інтерактивних методів і технологій.

На практичних заняттях із цих предметів застосовувалися активні й інтерактивні методи і технології навчання, а саме: мозковий штурм, дерево рішень, займи позицію, броунівський рух, дискусія, дебати, технологія співробітництва, робота у малих групах, відеоконференція. Попри це, проводилися рольові й ділові ігри, на яких застосовувалися засоби мультимедіа, «турнір архітекторів», складався електронний кросворд будівельної тематики, а також студентів навчали створювати веб-сайти англійською мовою 3 рекламою професійних послуг інженера-будівельника й архітектора.

Ми вважаємо, що реалізація даної педагогічної умови буде сприяти кращому засвоєнню знань, умінь, навичок та досвіду, необхідних для здійснення майбутніми інженерами-будівельниками професійної діяльності, оскільки під час ії реалізації нами було використано актуальні й розвивальні методи, які значно цікавіші за традиційні.

Після виконання всіх трьох педагогічних умов, на яких грунтувався формувальний експеримент, ми підрахували у \% його результати за всіма критеріями готовності.

Результати рівнів сформованості майбутніх інженерів-будівельників до застосування мультимедійних технологій у ході навчальної і майбутньої професійної діяльності за результатами констатувального експерименту відображені в табл. 2.

Таблиия 2

Рівні готовності майбутніх інженерів-будівельників до застосування мультимедійних технологій у ході навчальної і майбутньої професійної діяльності [за результатами формувального експерименту (у\%)]

\begin{tabular}{|c|c|c|c|c|}
\hline Рівні & Низький & Середній & Достатній & Високий \\
\hline Групи & 18 & 32 & 30 & 20 \\
\hline КГ & 34 & 44 & 17 & 5 \\
\hline
\end{tabular}

Так, із табл. 2 видно, що після проведення формувального експерименту рівні сформованості готовності студентів експериментальних груп до застосування мультимедійних технологій у ході навчальної і майбутньої професійної діяльності розміщено так: низький рівень готовності показали $18 \%$ студентів експериментальних груп і $34 \%$ студентів контрольних груп; середньому рівню відповідали $32 \%$ респондентів експериментальних і 44 \% контрольних груп; достатній рівень показали 
$30 \%$ респондентів експериментальних і $17 \%$ контрольних груп; високий рівень було виявлено у $20 \%$ студентів експериментальних і 5 \% контрольних груп.

Тепер проведемо порівняльну характеристику рівнів сформованості готовності майбутніх інженерів-будівельників до застосування мультимедійних технологій у ході навчальної і майбутньої професійної діяльності за результатами констатувального і формувального експериментів і з'ясуємо, які зміни відбулися у групах респондентів. Порівняльні дані рівнів сформованості готовності майбутніх інженерів-будівельників до застосування мультимедійних технологій у ході навчальної і майбутньої професійної діяльності за результатами констатувального i формувального експериментів відображено у табл. 3.

Таблиия 3

Рівні готовності майбутніх інженерів-будівельників до застосування мультимедійних технологій у ході навчальної і майбутньої професійної діяльності [ за результатами констатувального та формувального експериментів (у \%)]

\begin{tabular}{|c|c|c|c|c|c|}
\hline \multirow{2}{*}{ Групи } & \multirow{2}{*}{ Види експерименту } & \multicolumn{4}{|c|}{ Рівні (у \%) } \\
\cline { 3 - 6 } & констатувальний & 38 & 44 & 15 & 3 \\
\cline { 2 - 6 } & формувальний & 18 & 32 & 30 & 20 \\
\hline \multirow{2}{*}{ КГ } & констатувальний & 34 & 40 & 20 & 6 \\
\cline { 2 - 6 } & формувальний & 34 & 44 & 17 & 5 \\
\hline
\end{tabular}

Як свідчать дані таблиці 3, в експериментальних групах відбулися позитивні зміни у рівневій характеристиці сформованості готовності майбутніх інженерівбудівельників до застосування мультимедійних технологій у ході навчальної i майбутньої професійної діяльності.

Дані таблиці показують, що кількість студентів з низьким рівнем сформованості готовності до застосування мультимедійних технологій у ході навчальної і майбутньої професійної діяльності в експериментальних групах після проведення формувального експерименту зменшилася до $18 \%$ (було $38 \%$ ), а у контрольних групах кількість студентів 3 цим рівнем залишилася без змін (34\%), що майже у 2 рази більше, ніж в експериментальних групах.

Кількість студентів із середнім рівнем сформованості готовності до застосування мультимедійних технологій у ході навчальної і майбутньої професійної діяльності в експериментальних групах після проведення формувального експерименту зменшилася до $34 \%$ (було $44 \%$ ), а в контрольних групах кількість студентів 3 цим рівнем склала $44 \%$ (була 40 \%), що на 10 \% більше, ніж в експериментальних групах.

Кількість студентів 3 достатнім рівнем сформованості готовності до застосування мультимедійних технологій у ході навчальної і майбутньої професійної діяльності в експериментальних групах після проведення формувального експерименту збільшилася до $30 \%$ (було $15 \%$ ), а у контрольних групах кількість студентів з цим рівнем знизилася і склала $17 \%$ (було $20 \%$ ), що майже у 2 рази менше, ніж в експериментальних групах.

Кількість студентів 3 високим рівнем сформованості готовності до застосування мультимедійних технологій у ході навчальної і майбутньої професійної діяльності в 
експериментальних групах після проведення формувального експерименту збільшилася до $20 \%$ (було $3 \%$ ), а у контрольних групах кількість студентів 3 цим рівнем зменшилася і склала $5 \%$ (було $6 \%$ ), що у 4 рази більше, ніж в експериментальних групах.

\section{3. ВИСНОВКИ ТА ПЕРСПЕКТИВИ ПОДАЛЬШИХ ДОСЛІДЖЕНЬ}

Висновки. Результати формувального експерименту доводять доцільність застосування нашої методики, іiі ефективність і важливу роль у формуванні готовності майбутніх спеціалістів до застосування засобів мультимедіа, оскільки нині ця умова $\epsilon$ необхідною для успішного здійснення професійної діяльності, формування професійної компетентності i становлення кваліфікованих спеціалістів, які будуть конкурентноздатними на сучасному ринку праці.

Перспективи подальших досліджень. Експеримент із впровадження технології використання мультимедійних технологій у навчально-виховному процесі технічного ВНЗ інженерно-будівельного профілю був проведений в Одеській державній академії будівництва та архітектури (ОДАБА) і Київському національному університеті будівництва та архітектури (КНУБА). Ми вважаємо доцільним застосовувати цю технологію у технічних ВНЗ інженерно-будівельного профілю, тому що вона суттєво підвищує рівень володіння студентами засобів мультимедіа і роботи з ними, формує мотивацію до їх застосування, підвищує бажання не лише студентів, а й викладачів здійснювати навчальну діяльність за їхньої допомоги, що забезпечує її якість.

\section{СПИСОК ВИКОРИСТАНИХ ДЖЕРЕЛ}

1. Ананьев Б. Г. Человек как предмет познания / Б. Г. Ананьев. — Л. : Изд. Ленингр. ун-та, 1969. $339 \mathrm{c}$.

2. Деркач А. А. Акмеологические основы развития профессионала / А. А. Деркач. — Воронеж : НПО «Модэк», 2004. - $752 \mathrm{c.}$

3. Дьяченко М. И. Психологические проблемы готовности к деятельности / М. И. Дьяченко, Л.А. Кандыбович. - Минск : Изд-во БГУ, 1976. - 175 с.

4. Дьяченко М. И. Психология высшей школы : учебное пособие для магистров пед. спец. вузов / М. И. Дьяченко, Л. А. Кандыбович. - Минск : Тесей, 2003. - 352 с.

5. .Крутецкий В. А. Основы педагогической психологии / В. А. Крутецкий. - М. : «Просвещение», 1972. - $255 \mathrm{c}$.

6. Ліненко А. Ф. Теорія та практика формування готовності студентів пед. ВНЗ до професійної діяльності : автореф. дис. на здобуття наукового ступеня доктора пед. наук : спец. 13.00.04 «Теорія та методика професійної освіти» / А. Ф. Ліненко. — К., 1996. — 44 с.

Матеріал надійшов до редакиії 21.07.2013 року.

\section{ТЕХНОЛОГИЯ ПРИМЕНЕНИЯ МУЛЬТИМЕДИА В УЧЕБНО-ВОСПИТАТЕЛЬНОМ ПРОЦЕССЕ ТЕХНИЧЕСКОГО ВУЗА ИНЖЕНЕРНО-СТРОИТЕЛЬНОГО ПРОФИЛЯ}

Дубинина Наталья Васильевна аспирантка кафедры педагогики Одесский национальный педагогический университет им. К. Д. Ушинського, Одесса, Украина natali.dubinina@bk.ru

Аннотация. Данная статья посвящена описанию технологии применения мультимедиа в учебно-воспитательном процессе технического высшего ученого заведения инженерно- 
строительного профиля в ходе учебной и будущей профессиональной деятельности. В ней рассказывается о стадиях подготовки будущих инженеров-строителей к применению средств мультимедиа в ходе учебной и будущей профессиональной деятельности, а также о проведении констатирующего и формирующего экспериментов, которые доказывают целесообразность предложенной методики, её эффективность и положительные результаты, которые отражаются на современном учебном процессе технического высшего учебного заведения инженерно-строительного профиля.

Ключевые слова: готовность; модель; технология; мультимедийная технология; ВУЗ; инженер-строитель; будущая профессиональная деятельность.

\title{
THE TECHNOLOGY OF MULTIMEDIA USE \\ IN THE EDUCATIONAL PROCESS OF HIGHER TECHNICAL SCHOOL OF CIVIL- ENGINEERING PROFILE
}

\author{
Nataliya V. Dubinina \\ post-graduate student of Pedagogic Department \\ Odessa National Pedagogical University after K.D. Ushinskiy, Odessa, Ukraine \\ natali.dubinina@bk.ru
}

\begin{abstract}
The given article is devoted to the description of multimedia technology and its use in the educational process of the technical higher educational establishment of civil-engineering profile while educational and future professional activity. It considers the stages of future civilengineers' preparation for the use of multimedia and carrying out the verifying and forming experiments that prove the purposefulness of our methods, its effectiveness and positive results that are reflected on the modern educational process of higher technical school of civil-engineering profile.
\end{abstract}

Key-words: readiness; model; technology; multimedia technology; higher educational establishment; a civil-engineer; future professional activity.

\section{REFERENCES (TRANSLATED AND TRANSLITERATED)}

1. Ananiev B. G. A man as a subject of knowledge. - L., Izd. Leningr. un-ta, 1969. — 339 s. (in Russian)

2. Derkach A. A. Akmeological bases of development of a professional/I.O. Mosk. Psychological-sozial. un-ty: Voronezh: NPO “Modek", 2004. — 752 s. (in Russian)

3. Diachenko M. I., Kandibovich L. A. Psychological problems of readiness to the activity. — Minsk : Izdvo BGU, 1976. - 175 s. (in Russian)

4. Diachenko M. I., Kandibovich L. A. Psychology of higher school: Educational supply for masters of ped. special higher educational establishments. — Minsk : Tesei, 2003. — 352 s. (in Russian)

5. Krutetski V. A. The bases of pedagogical psychology. - M. : "Prosveshchenie", 1972. — 255 s. (in Russian)

6. Linenko A. F. Theory and practice of forming of ped. universities students' readiness to the professional activity: author report of dis. for getting of scientific degree of the doctor of pedagogics : speciality 13.00.04 "Theory and methodics of professional education"/ A. F. Linenko. — K., 1996. — 44 s. (in Russian) 